\title{
O LUGAR DO PSICÓLOGO NO CONTEXTO DE URGÊNCIA E EMERGÊNCIA
}

\author{
Simone Corrêa Silva ${ }^{1}$ \\ 1. Psicóloga formada pela Universidade Presbiteriana Mackenzie, com especialização em \\ Psicologia na Área Hospitalar pelo ICHCFMUSP; Mestre em Psicologia Escolar e do \\ Desenvolvimento Humano pelo IP-USP. Atualmente, compõe e coordena o Serviço de \\ Psicologia do Hospital Municipal do Campo Limpo. \\ monecorrea.si@gmail.com
}

\section{Resumo}

O trabalho do psicólogo no hospital acontece por meio da ocupação de um lugar que precisa ser esclarecido e apropriado. Para tanto, torna-se preciso definir esse lugar não como um espaço físico, mas como uma disponibilidade emocional que se sustenta por um éthos próprio e por uma atitude clínica. Portanto, trata-se de um trabalho que se diferencia por meio do fazer, cuidando do ser psicólogo. Refere-se a uma atitude de cuidado e atenção com escuta e olhar voltados àquele que expressa um sofrimento. No contexto de urgência e emergência, esse trabalho deve estar articulado com a realidade institucional e cotidiana, dando voz à urgência psicológica, mas sem obstacularizar a passagem da ordem objetiva da instituição.

\section{Definição de lugar}

Ao abordarmos o trabalho do psicólogo numa unidade de pronto socorro, torna-se importante discutirmos o seu lugar neste contexto de urgência e emergência. Para tanto, devemos ressaltar que lugar está a priori de papel, tarefa ou função. Transcende o espaço físico e diz respeito a uma atitude de disponibilidade emocional, mediante as situações diversas que se dão em termos de tempo e espaço no hospital. Além da

\section{Referência:}

Silva, Simone Corrêa. O Lugar do Psicólogo no Contexto de Urgência e Emergência. In: Anais da V Jornada de Psicologia no Hospital Municipal do Campo Limpo [= Blucher Medical Proceedings, vol.1, num.6]. São Paulo: Editora Blucher, 2015.

DOI 10.5151/medpro-5jphmcl-005 
competência técnica, essa atitude deve estar articulada a um reconhecimento e enfrentamento da realidade implicada pelo contexto institucional.

\section{Clínica e ética como pilares do fazer psicológico}

A partir desta atitude, o psicólogo vai ocupando o seu lugar, por meio, inclusive, de sua atuação clínica e ética. Lembrando que, etimologicamente, ética origina-se de éthos (latim) e significa um modo de habitar uma morada e a forma como o costume e conduta são desempenhados nesta. E clínica origina-se de klinein (do grego) e se refere ao seu modo de atuação, que está a priori de sua localização. Etimologicamente, clínica significa o cuidado que se debruça àqueles que experimentam o sofrimento de algo.

Sob inspiração do mito de Héstia, o lugar do psicólogo será o da moradia e do encontrar; do aproximar e do estar junto. Sua ocupação, portanto, se dará através de um modo de ser e de estar.

Mitologicamente, Héstia é uma anfitriã afável e que prevê hospitalidade e provê hospitalização, quando necessário. Coloca-se disponível para receber aqueles que por ela quisessem procurar. Ela os acolhia e ouvia suas histórias; com isso, possibilitava que cada um retornasse ao seu centro pessoal. Depois de acolhidos, aquecidos e reintegrados, cada um podia, assim, retornar a seu mundo, restabelecido (Freitas, 2005).

Nesse lugar, torna-se preciso sustentar seu éthos e posicionar-se de forma a se relacionar com o outro sendo convocado para uma atitude de atenção e prontidão para compartilhar o momento que o usuário do serviço lhe compartilha (Bonaventure, 1997).

Ao sustentar seu éthos, o profissional estará sustentando sua morada, apoiando-se em seu modo de ser no mundo e consigo mesmo, em seu exercício de vida, em sua atitude diante da e na vida, refletida também em seu trabalho. E carregará consigo essa atitude ao compartilhar com o outro a experiência que ao profissional não pertence, mas que pode ser escutada, acolhida e cuidada dentro do limite do possível e a partir do que o usuário lhe confiar.

Torna-se preciso destacar que um setting é construído e alicerçado não apenas pelo psicólogo, mas a partir da relação que se estabelece entre ele e o usuário do serviço, independente do quesito tempo. O tempo do encontro será o do possível, naquele momento, naquela relação composta por cada um deles, naquela instituição. 
Mas, a lareira de Héstia deve sempre estar acesa, sendo o lugar de passagem. E, nesse sentido, proporcionar o estar para que se restabeleça o cuidar de ser e se possa resgatar novos modos de continuar sendo. Não podemos nos esquecer que o hospital é um lugar de passagem e de trânsito, por onde o usuário transita num determinado momento e circunstância de sua vida.

A diferença do trabalho do psicólogo estará no como fazer, ou seja, na ação. O uso da técnica e o desempenho do especialista não devem sobrepujar o lugar do clínico.

\section{O fazer psicológico no contexto de urgência e emergência}

Dentro do contexto de urgência e emergência, essencial se faz que o psicólogo possa, com clareza para sustentar sua atitude clínica no lugar que lhe cabe, desenvolver a habilidade para transitar entre a subjetividade do usuário e a objetividade do contexto institucional em seu cotidiano. Assim, a atenção psicológica precisa abrir passagem para cuidados da ordem objetiva do hospital que também possuem uma emergência. Porém, sem perder de vista a sua pronta-escuta psicológica para escuta, acolhimento e encaminhamento da urgência e emergência que pedem cuidado emocional.

Geralmente, a emergência psicológica corresponderá a um conteúdo que surgirá como queixa, diferenciando-se de pedido e de demanda. Pedido, diz respeito ao que se intenciona frente ao sofrimento. Demanda define-se pelo que urge, mostrando-se urgente e que precisa de atenção e cuidado. Demanda ainda significa confiança e entrega, remetendo-nos à ideia de procurar, buscar, caminhar para (Morato, 2008).

O trabalho do psicólogo frente à queixa, ao pedido e à demanda se dará na medida do que lhe for possível permitido e confiado a partir de sua relação com o usuário. A atitude de prontidão, contemplada pela escuta e o olhar atentos e de cuidado, possibilitarão passagem para o resgate de potencialidades do próprio usuário na busca de modos de cuidar de seu sofrer e encaminhar-lhe sentidos (em termos de direcionamento).

\section{Considerações finais}

Cabe ao psicólogo fazer a escolha de seu lugar dentro de uma equipe de pronto socorro, obtendo e expressando clareza de seu éthos na especificidade de sua atuação. 
Mas, vale lembrar que o lugar do psicólogo no contexto de urgência e emergência nunca estará pronto, pois deve estar implicado num processo de constante construção.

O lugar do psicólogo nesse contexto, refere-se a uma atitude pautada na clínica e num éthos próprio, que se traduz numa prontidão emocional por meio da escuta, da atenção e do cuidado. Um lugar, portanto, que precisa ser esclarecido, expresso, apropriado e sustentado.

\section{Referências Bibliográficas:}

1. Bonaventure, L. (1997). Prólogo. In H. K. Fierz. Psiquiatria Junguiana (pp. 15-20). São Paulo: Paulus.

2. Bruscato, W. L., C. Benedetti \& Lopes, S. R. A. (2004). A prática da psicologia hospitalar na Santa Casa de São Paulo: novas páginas em uma antiga história. São Paulo: Casa do psicólogo.

3. DeMarco, M.A. (2003). A face humana da medicina: do modelo biomédico ao modelo biopsicossocial. São Paulo: Casa do psicólogo.

4. Freitas, L.V. (2005). O calor e a luz de Héstia: sua presença nos grupos vivenciais (Edição Especial). Cadernos de Educação: UNIC-CPG.

5. Furigo, R. C. P. L. (2006). Plantão psicológico: uma contribuição da clínica junguiana para Atenção Psicológica na área da saúde. Tese de Doutorado, Programa de Pós-Graduação em Psicologia - Centro de Ciências da Vida. Pontifícia Universidade Católica de Campinas, Campinas.

6. Gadamer, H-G. (2006). O caráter oculto da saúde. Petrópolis: Vozes.

7. Jacoby, M. (1987). O encontro analítico: transferência e relacionamento humano. São Paulo: Cultrix.

8. Jung, C. G. (1971/1985). A prática da psicoterapia: contribuições ao problema da psicoterapia e à psicologia da transferência (Obras Completas de C. G. Jung, v. XVI/1). Petrópolis: Vozes.

9. Morato, H. T. P. (2006). Pedido, queixa e demanda no plantão psicológico: querer, poder ou precisar. In Anais, VI Simpósio Nacional de Práticas Psicológicas em Instituição Psicologia e Políticas Públicas (pp. 38-43). Vitória - Espírito Santo: UFES, 1.

10.Morato, H. T. P. (2008). Prática psicológica em instituições: ação política. In Anais, VIII Simpósio Nacional de Práticas Psicológicas em Instituição - Atenção psicológica: experiência, intervenção e pesquisa. São Paulo: Universidade de São Paulo. Recuperado em 09 de dezembro de 2014, de 
http://www.lefeusp.net/arquivos_diversos/VIII_simposio_anpepp/textos\%20pesquisadores/ morato08.pdf

11.Silva, S. C. (2011). Cuidando de ser psicólogo no hospital: uma cartografia de experiências da construção de um lugar, contadas sob inspiração da psicologia analítica de C. G. Jung. Dissertação de Mestrado, Instituto de Psicologia Universidade de São Paulo, São Paulo.

12.Silva, S. C. \& Freitas, L.V. (2009). A que(m) o psicólogo deve servir no hospital? Um contar de ideias sobre a construção de um lugar, a partir de narrativas com o jogo de areia (pp. 514517), In Anais, V congresso Latinoamericado de Psicologa Junguiana. Santiago de Chile: Centro de Convenções Sheraton. Recuperado em 09 de dezembro de 2014, de http://congresso.cgjung.cl/pdf/ed_digita_psicologia_junguiana.pdf 